University at Buffalo School of Law

Digital Commons @ University at Buffalo School of Law

\title{
Sustainable Decentralization: Power, Extraconstitutional Influence, and Subnational Symmetry in the United States and Spain
}

James A. Gardner

University at Buffalo School of Law

Antoni Abat i Ninet

Follow this and additional works at: https://digitalcommons.law.buffalo.edu/journal_articles

Part of the Comparative and Foreign Law Commons, and the Constitutional Law Commons

\section{Recommended Citation}

James A. Gardner \& Antoni A. i Ninet, Sustainable Decentralization: Power, Extraconstitutional Influence, and Subnational Symmetry in the United States and Spain, 59 Am. J. Comp. L. 491 (2011).

Available at: https://digitalcommons.law.buffalo.edu/journal_articles/205

James A. Gardner, Sustainable Decentralization: Power, Extraconstitutional Influence, and Subnational Symmetry in the United States and Spain, 59 Am. J. Comp. L. 491 (2011), 10.5131/AJCL.2010.0019.

\section{C) ${ }_{\text {COPYRIGHT }}^{\text {N }}$}

This Article is brought to you for free and open access by the Faculty Scholarship at Digital Commons @ University at Buffalo School of Law. It has been accepted for inclusion in Journal Articles by an authorized administrator of Digital Commons @ University at Buffalo School of Law. For more information, please contact lawscholar@buffalo.edu. 


\title{
SUSTAINABLE DECENTRALIZATION: POWER, EXTRACONSTITUTIONAL INFLUENCE, AND SUBNATIONAL SYMMETRY IN THE UNITED STATES AND SPAIN
}

\author{
James A. Gardner \\ University at Buffalo Law School \\ State University of New York \\ Antoni Abad i Ninet \\ Institute of Law and Technology \\ Universitat Autònoma de Barcelona \\ and \\ University at Buffalo Law School \\ State University of New York
}

Forthcoming, American Journal of Comparative Law, Vol. 58 (April, 2011)

\begin{abstract}
In the Madisonian tradition of constitutional design, the foundation of a sustainable federalism is thought to be a scientifically precise balancing of national and subnational power. Experience shows, however, that national and subnational actors in highly diverse systems are capable of developing a rich array of extraconstitutional methods of mutual influence, so that the formal, constitutionalized balance of power rarely settles the question of the actual balance of power between levels of government. A more important factor in ensuring the long-term sustainability of a meaningfully federal system is the degree of symmetry across subnational units in their relation to the central state. A comparison of the U.S. and Spain suggests that federalism is most directly threatened when subnational units compete not collectively with the central state, thereby checking its power, but with each other, a condition that furnishes the central state with opportunities to exploit subnational rivalries in ways that risk genuine, long-term destabilization.
\end{abstract}

December 17, 2010 


\title{
SUSTAINABLE DECENTRALIZATION: POWER, EXTRACONSTITUTIONAL INFLUENCE, AND SUBNATIONAL SYMMETRY IN THE UNITED STATES AND SPAIN
}

\author{
James A. Gardner* \\ Antoni Abad i Ninet ${ }^{* *}$
}

\section{INTRODUCTION}

Since the middle of the last century, a consensus seems to have begun to emerge, at least in the West, that the modern nation state is best and most sensibly organized when its domestic powers are to some degree decentralized. Whether rooted in a post-War fear of tightly centralized power as a route to tyranny, a post-Communist rejection of the feasibility of central state planning, or any of a host of welfarist theories that are frequently invoked to justify contemporary federalism, decentralization of official power has come to be seen as essential to good governance, if not indeed indispensable to the successful and sustainable practice of mass democracy. Many of the world's most successful new democracies, along with those that aspire to success (e.g., India, Brazil, South Africa, Argentina) have been founded or refounded on formal principles of federalism. Other nations that have already enjoyed success as democracies have sought to ensure it in the future through deliberate programs of devolution and decentralization (e.g., United Kingdom, Belgium, Italy). And of course this very question has

Vice Dean for Academic Affairs and Joseph W. Belluck and Laura L. Aswad Professor of Civil Justice, University at Buffalo Law School, State University of New York.

\footnotetext{
Institute of Law and Technology, Universitat Autònoma de Barcelona; Affiliated Faculty, Edwin
} F. Jaeckle Center for State and Local Democracy, University at Buffalo Law School, State University of New York, 
dominated recent debates and negotiations concerning the ultimate structure of the European Union.

This commitment to decentralization does not, however, rest on the belief that democracy somehow entails decentralization as a matter of theoretical necessity. Indeed, in some respects the formal structures of federalism stand in opposition to national democratic aspirations, as the recent American agitation over the Electoral College attests. Rather, the spreading commitment to decentralization seems to flow more from a pragmatic belief that democratic self-governance is best sustained over the long term when state power is shared to at least some extent, and for at least some purposes, by national and subnational levels of government. As a result, some of the most pressing questions facing modern democratic states and constitutional designers concern the degree to which power should be decentralized and the kinds of institutions that are best capable of sustaining the pragmatically ideal distribution of national and subnational power in any given place.

In modern constitutional law, these concerns typically manifest themselves in two closely related aspects of constitutional structure: (1) the specific constitutional allocation of competencies (powers) to each level of government; and (2) the general constitutional default rule dictating where power presumptively lies when the constitution is silent. Especially in the Madisonian tradition of constitutional design, in which a scientifically precise balancing of opposing forces is seen as the key to institutional sustainability, ${ }^{1}$ achieving just the right combination of express power allocations and residual power default rules is typically thought to

1 The Federalist, Nos. 48-51 (James Madison) (Clinton Rossiter, ed. 1961). The prevalence of scientific imagery and the aspiration to scientific validity in the constitutional thought of the founding generation is well-documented in Michael Kammen, A Machine That Would Go of Itself: The Constitution in American Culture (1986). See also, e.g., INS v. Chadha, 462 U.S. 919, 951 (1983) (describing the constitutional system of separated powers as "a single, finely wrought and exhaustively considered procedure"). 
be the indispensable foundation for a successful decentralized state. An appropriate constitutional symmetry between national and subnational power, in other words, is the precondition for a sustainable decentralization of official power. To give too much power to the national government risks an inward collapse toward centralization and its attendant dangers; to give excessive power to subnational units risks the fragmentation of the state and the consequent loss of the many benefits and protections it might otherwise provide.

In this paper, we wish to dispute this account. In our view, constitutional allocations of power and default rules are not the most important factors determining the long-term viability of federal or otherwise decentralized states. In fact, experience shows that national and subnational actors are capable of developing a rich array of extraconstitutional methods of mutual influence, and that the formal, constitutionalized balance of power therefore rarely settles the question of the actual balance of power between levels of government. Initial asymmetries of power enshrined in constitutions can thus be altered by informal arrangements and workarounds, moderating the dangers of instability posed by ill-advised or poorly executed initial constitutional endowments.

In contrast, we contend that a more important factor in ensuring the long-term sustainability of a meaningfully federal system is the degree of symmetry across subnational units (states, provinces, cantons, Länder, etc.) in their relation to the central state. The real threat to the stable, long-term exercise of decentralized forms of power arises when subnational units develop interests in their relation to national power that conflict with the interests of other such units. To put this proposition in its most general terms, federalism and other forms of decentralization are most directly threatened when subnational units fail to maintain a united 
front in dealing with national power. In these circumstances, states and provinces compete not collectively with the central state, thereby checking its power, but with each other, a condition that furnishes the central state with opportunities to exploit subnational rivalries in ways that risk genuine, long-term destabilization.

Asymmetry of power, we therefore conclude, is more dangerous in its horizontal than in its vertical dimension. We will demonstrate this proposition with numerous examples from two systems that strike very different balances: the United States and Spain. The argument proceeds as follows. Part II of this paper describes the Madisonian model of contestatory federalism, in which system-wide stability - and ultimately individual liberty - is secured as a matter of constitutional design by the exacting allocations of national and subnational power. Part III demonstrates that a vertically symmetrical initial constitutional allocation of power is less important than the Madisonian model predicts because of the ability of official actors to develop significant extraconstitutional methods of mutual influence. This allows each level of government to check the other's power in ways that the long-term stability of the system may require, but for which no formal constitutional provision has been made. Such avenues of influence, moreover, are capable of arising in widely divergent systems characterized by very different initial constitutional allocations of power.

Part IV demonstrates that a much more serious long-term threat to the sustainability of balanced, decentralized power can arise from horizontal asymmetry of interests across subnational units. Here, much can be learned from a comparison between the generally uniform relations of the American states to the United States government, on the one hand, and the starkly divergent relations between Spanish Autonomous Communities and the Spanish central 
government, on the other. Moreover, we will argue, in the presence of such horizontal asymmetry of interest, the design of constitutional structures of national-subnational relations can have important and unanticipated consequences.

\section{The Madisonian Model of Contestatory Federalism}

There are many different kinds of, and justifications for, federal and other decentralized arrangements of governmental power. ${ }^{2}$ Here, however, we focus on "contestatory" federalism, a conception of divided power that justifies federalism as a method of protecting liberty through the institutionalization of a permanent contest for power between national and subnational units of government. This is the justification most closely associated with the brand of federalism practiced in the United States, and most clearly articulated by James Madison in $1787 .^{3}$

"The accumulation of all powers . . in the same hands," wrote Madison in Federalist No. 47, "may justly be pronounced the very definition of tyranny." To protect liberty, on this view, power must be divided. Federalism serves this purpose by parceling out government powers among different levels of government, giving each level of government, national and subnational, powers sufficient to allow each to monitor and check the abuses of the other. ${ }^{5}$ Although power is fragmented in such a system, its use is unified because each level of

2 See, e.g., Thomas Dye, American Federalism (1990); Robert A. Schapiro, Polyphonic Federalism (2009), ch. 3; Daniel Elazar, American Federalism: A View from the States (1984).

3 This section draws liberally on James A. Gardner, In Search of Subnational Constitutionalism, 4 Eur. Const. L. Rev. 325 (2008).

4 The Federalist, supra note 1, No. 47, at 301.

$5 \quad$ Andrzej Rapaczynski, From Sovereignty to Process: The Jurisprudence of Federalism after Garcia, 1985 Sup. Ct. Rev. 341, 380-95. 
government pursues the same goal: serving the interests of the people. ${ }^{6}$ As Madison put it, "[t]he federal and State governments are in fact but different agents and trustees of the people, constituted with different powers and designed for different purposes."7 $\quad$ Federalism, on this model, is a dynamic system designed to be manipulated by the people to produce results they desire. Hamilton put this point clearly:

[I]n a confederacy the people, without exaggeration, may be said to be entirely the masters of their own fate. Power being almost always the rival of power, the general government will at times stand ready to check the usurpations of the state governments, and these will have the same disposition towards the general government. The people, by throwing themselves into the scale, will infallibly make it preponderate. If their rights are invaded by either, they can make use of the other as the instrument of redress. ${ }^{8}$

On the American Framers' view of federalism, then, popular allegiance to any government is not organically fixed, but rather will ebb and flow according to that government's instrumental value to the populace at any given time. ${ }^{9}$ Contestatory federalism therefore does not define a static relation among national and subnational governments, but a living, dynamic one, and subnational governments must accordingly have sufficient autonomy and power to play their assigned roles.

\footnotetext{
6 Vincent Ostrom, The Political Theory of a Compound Republic 23 (1987).

$7 \quad$ The Federalist, supra note 1, No. 46 (Madison), at 294.

8 The Federalist, supra note 1, No. 28 (Hamilton), at 180-81.

9 Akhil Reed Amar, Of Sovereignty and Federalism, 96 Yale L.J. 1425 (1987); Martin Landau, Federalism, Redundancy, and System Reliability, 3 Publius 173 (1973); Dye, supra note 2, at 6; Todd E. Pettys, Competing for the People's Affection: Federalism's Forgotten Marketplace, 56 Vand. L. Rev. 329 (2003).
} 
Precisely how much power, then, must each level of government possess in order to create a system of perpetual, mutual conflict among levels of government? Madison never purports to provide a universal answer to this question, even if he thought one existed, but he does suggest that to design a successful and sustainable constitutional system of federalism requires considerable forethought and painstaking calculation of an almost scientific quality. The U.S. Supreme Court has endorsed this view, describing the constitutional allocation of government power as "a single, finely wrought and exhaustively considered procedure" 10 that generally requires strict judicial policing to prevent deviations from the constitutional plan. ${ }^{11}$

Notwithstanding the rapid expansion of U.S. national power in the twentieth century, contestatory federalism to this day is woven into the structure of American intergovernmental relations. Although it does not describe the historically dominant relationship between the state and national governments, which has more often been cooperative than hostile, ${ }^{12}$ intergovernmental contestation remains nonetheless a background potentiality built into the system that influences the ways in which the two levels of government interact. ${ }^{13}$

11 A host of other Supreme Court decisions illustrate the Court's belief that painstaking fidelity to the original plan of power allocation is required for the long-term survival of the constitutional system, and ultimately of liberty itself. See, e.g., New York v. United States, 505 U.S. 144 (1992); United States v. Lopez, 514 U.S. 549 (1995); Printz v. United States, 521 U.S. 898 (1997); United States v. Morrison, 529 U.S. 598 (2000). Although it is by no means clear that constitutional allocations of power were meant originally to be enforced judicially Madison certainly seemed to contemplate a more overtly political form of contestation and struggle - the Supreme Court early on construed its own role to be one of umpiring disputes between state and national power, and deciding them in accordance with constitutionalized decisions concerning power allocations. McCulloch v. Maryland, 17 U.S. 316 (1819).

12 Morton Grodzkins, The American System: A New View of Government (1968); Elazar, supra

note 2 . "sanctions" designed into federal systems). 
Consequently, the American states have frequently understood themselves, and have been understood by their inhabitants, as important, autonomous, and often effective defenders of the interests of the local citizenry against the central state. As Madison anticipated, U.S. states have a long record of inserting themselves between their citizens and Washington, and of deploying their powers in ways intended self-consciously to thwart the operation of national policies that they have determined to be destructive of their citizens' liberties and others interests. Examples include the Virginia and Kentucky Resolutions of 1798, which loudly protested the national government's suppression of political criticism; the Nullification Crisis of 1832, in which South Carolina threatened to use force to prevent national customs officials from collecting tariffs on goods unloaded in Charleston Harbor; numerous instances in which states have refused to cooperate with national officials in the implementation of national regulatory regimes; and the frequent use today by states of lawsuits to challenge national regulatory authority. ${ }^{14}$

\section{Vertical Symmetry OF Power and Extraconstitutional AVEnUES Of InfluenCe}

The constitutional decentralization of governmental power may be achieved in many different ways. Powers may be expressly allocated to different levels of government. Such powers may be granted exclusively to one level of government, or they may be concurrent. If concurrent, they may be shared across the range of possible uses of the power, or different aspects of the power may be isolated and parceled out to different levels of government. Where concurrent powers come into conflict, such conflicts may be resolved in favor of one level or the

14 These and many other incidents are described in James A. Gardner, Interpreting State Constitutions (2005), ch. 3 . 
other. Where the constitution is silent, default rules may provide for the allocation of residual power to one level or another. ${ }^{15}$

Such constitutional allocations of power doubtless have important ramifications for both the possibility of mutual checking in a federal system and its efficacy. Nevertheless, constitutional rules of power allocation do not structure national-subnational relations in their entirety, nor do they provide the exclusive means by which national and subnational power may mutually check each other. Instead, some potential seems always to exist for the development of informal and extraconstitutional means of mutual influence among levels of government. Here, we illustrate the emergence of such methods of influence in two systems with very different initial power allocations: the American system of formal federalism, and the Spanish system of decentralization by sufferance.

\section{A. The United States: Subnational Power in a Regime of UnPlanNed National CENTRAlization}

The contemporary allocation of power between the national and subnational governments in the United States has wandered far from the original constitutional plan. Members of the founding generation were for the most part deeply suspicious of concentrated, centralized power, the model of national empire against which they revolted. ${ }^{16}$ As a result, even those who professed the need to create a stabilizing central authority agreed that doing so entailed serious risks. The Framers solved this problem by creating a national government which they believed would have the power to do what needed to be done nationally, but nothing else - a national

\footnotetext{
15 See Ronald L. Watts, Comparing Federal Systems (3d ed. 2008), for numerous examples.

16 Malcolm M. Feeley and Edward Rubin, Federalism: Political Identity and Tragic Compromise 101-102 (2008).
} 
government of strong but nevertheless limited powers. This solution was implemented through a constitutional decentralization of power that created a national government of limited and enumerated powers and allocated all general and residual powers to the subnational level. ${ }^{17}$

During the republic's first half-century, the actual balance of power between national and subnational power adhered closely to the original plan. The states dominated most aspects of public affairs, the national government remained small and relatively weak, and the political identity of most Americans revolved around their state and local governments rather than the nation. ${ }^{18}$ The Civil War marked the beginning of a long period of change in this constitutional settlement. Successful prosecution of the war required, for the first time, a significant accumulation of power at the national level and even, according to some historians, the invention and deliberate propagation of a national identity to legitimate the sacrifices that northerners and unionists were asked to endure, and to justify the eventual reuniting by force of the continental nation. ${ }^{19}$

By the late twentieth century, the conditions of modernity had intruded so far on the original constitutional plan that the actual distribution of power between national and subnational governments tipped dramatically in favor of national power. The growth of the administrative state, the exigencies of fighting two world wars and the Great Depression, and the ultimately supportive role of the federal government in the civil rights movement conferred great legitimacy

17 U.S. Const., amend. X: "The powers not delegated to the United States by the Constitution, nor prohibited by it to the States, are reserved to the States respectively, or to the people"; McCulloch v. Maryland, 17 U.S. 316 (1819).

18

Gordon S. Wood, Foreword: State Constitution-Making in the American Revolution, 24 Rutgers Law Journal 911 (1993). 
on the national government at the expense of the states. ${ }^{20}$ During a period spanning more than four decades, moreover, the Supreme Court conferred constitutional legitimacy on these developments in a series of rulings that ratified the huge expansion of national power that had occurred in practice. ${ }^{21}$

In these circumstances, it might be assumed that subnational power in the United States has become largely irrelevant, yet this is far from true. In fact, even in conditions that are hostile to the effective exercise of formal subnational power, the American states have nevertheless managed to develop a wide variety of techniques - some clearly contemplated by the Constitution, others less so - for successfully protecting themselves against national power, asserting the interests of their citizens against invasion by the national government, and influencing the direction and content of national policy.

1. Threats of Violent Resistance. Among the most potent - and riskiest extraconstitutional strategies American states have employed is the use or threat of force to resist exercises of national power. ${ }^{22}$ Although the ultimate use of force - secession - failed badly, states have occasionally resorted to force in smaller and more calculated ways to get what they want. The Nullification Crisis is probably the most prominent example. In 1832, the national government enacted a protectionist tariff that many Southerners felt benefitted northern industrial interests at the expense of the southern economic interest in agricultural exports. In response, South Carolina raised a small army, which it threatened to deploy to block any effort

$20 \quad$ Feeley and Rubin, supra note 16, at 110-15.

21 E.g., NLRB v. Jones \& Loughlin Steel Corp., 301 U.S. 1 (1937); Wickard v. Filburn, 317 U.S. 111 (1942); Heart of Atlanta Motel v. U.S., 379 U.S. 241 (1964); Katzenbach v. Morgan, 384 U.S. 641 (1966).

22 The following examples are drawn from Gardner, supra note 14 
by national customs officials to collect the tariff in the port of Charleston. The threat of violence was eventually defused when the national government took careful steps to avoid any outright provocation, and South Carolina ultimately backed down from its threat to use force. Nevertheless, shortly after resolution of the crisis, Congress in 1834 enacted the Compromise Tariff, which phased out over a period of nine years the provisions to which South Carolinians objected. ${ }^{23}$ While South Carolina was not able to obtain precisely what it wanted, as quickly as it wanted, its threatened use of force clearly influenced the content of national law.

Another, more recent example of a state's threatened use of force is the 1957 saber-rattling of Arkansas in response to national efforts to implement a federal judicial order requiring the desegregation of Central High School in Little Rock, the state capital. Arkansas Governor Orval Faubus, vowing to resist federal enforcement of the desegregation order, deployed the National Guard at the school forcibly to prevent the student plaintiffs from entering the building. ${ }^{24}$ As a confrontation brewed, the governor withdrew the troops, leaving the students to face a white mob. President Eisenhower then sent in a thousand troops from the $101^{\text {st }}$ Airborne Division, a regular United States military unit, to enforce the court order and keep the peace. ${ }^{25}$

Even more recently, states have threatened physical confrontation with the national government over issues of environmental policy. Prompted largely by national legislation that restricted grazing on public lands, Nevada in 1979 enacted legislation "declaring state

23 For a good account of these events, see William W. Freehling, Prelude to Civil War: The Nullification Controversy in South Carolina, 1816-1836 (1966).

24 See Taylor Branch, Parting the Waters: America in the King Years, 1954-63 (1989), at 222-24.

25 Id. 
sovereignty over 49 million acres of Nevada territory" owned by the national government and managed by the Bureau of Land Management. ${ }^{26}$ Although this so-called "Sagebrush Rebellion" ${ }^{27}$ never led to organized violence against the national government by any state, a more serious incident occurred in 1988 when Idaho Governor Cecil Andrus deployed police at the state border to seize a railway shipment of radioactive waste generated at a federal nuclear facility in Colorado. ${ }^{28}$ Andrus had the shipment seized pursuant to a state-declared policy of refusing to accept additional nuclear waste from out-of-state. As recently as 2002, the Governor of South Carolina made a similar threat to block at the border trucks containing weapons-grade plutonium destined for a federal storage site in the state. ${ }^{29}$

2. Weak Defiance. In addition to these outright illegal means of resisting national power, states also have at their disposal a number of what might be termed "quasi-legal" strategies for influencing national policy. One such strategy is a deliberate failure fully to comply with or to enforce binding federal law. Here, the state does not overtly defy national law, but nevertheless attempts, in the guise of implementing it, to undermine it by half-hearted or inappropriate measures. For example, in 1975, as part of an energy policy designed to conserve oil, Congress lowered the speed limit on all roads to 55 miles per hour. While most states responded by complying, Montana complied in an extremely half-hearted way. Instead of

26 Paul Wallace Gates, Pressure Groups and Recent American Land Policies 3 (1980).

27 For an overview of this "sagebrush rebellion," see William L. Graf, Wilderness Preservation and the Sagebrush Rebellions 225-32 (1990); R. McGreggor Cawley, Federal Land, Western Anger: The Sagebrush Rebellion and Environmental Politics 109-10 (1993).

28 Fox Butterfield, Idaho Firm on Barring Atomic Waste, New York Times, Oct. 23, 1988, 1:32.

29 David Firestone, S. Carolina Battles U.S. on Plutonium, New York Times, Apr. 12, 2002, at A21; Matthew Boedy, Governor Declares State of Emergency, Augusta Chronicle, June 15, 2002, at A01. 
enforcing violations of the 55-mile-per-hour speed limit as traffic infractions, it issued five-dollar "environmental" citations to drivers traveling above 55 m.p.h., but below what Montana police considered a safe speed. ${ }^{30}$ Violations were not charged against drivers' insurance records. This kind of "enforcement" worked to undermine the congressional objective since it both declared quite plainly the state's continuing opposition to the national policy, and all but invited the public to exceed the national speed limit with impunity within the borders of the state - an invitation that drivers, predictably, took up with enthusiasm. ${ }^{31}$

3. Political Influence. In addition to resistance and defiance, American states have several fully legal avenues of recourse to influence the way in which national power is exercised. First and foremost is the influence of national legislation through political means. ${ }^{32}$ State officials often have the capacity, for example, to press the state's congressional delegation to work for the enactment at the national level of policies favored by the state. ${ }^{33}$ For a decade, this view of state influence induced the United States Supreme Court to abandon any attempt to enforce constitutional limits on the national commerce power, a position from which it has since

30 According to news accounts, the "conventional wisdom" was that no serious infractions would be charged for daytime driving below about $85 \mathrm{mph}$ in good weather conditions. Tom Kenworthy, New Life in the Fast Lane: Wide-Open Throttles in Wide Open Spaces, The Washington Post, Dec. 9, 1995, at A3.

31 Robert E. King and Cass R. Sunstein, Doing Without Speed Limits, 79 B.U. L. Rev. 155, 157-162 (1999); Timothy Egan, Speeding Is Easy (and Almost Free) in Montana, New York Times, July 10, 1989, at A14:3.

32 See Herbert Wechsler, The Political Safeguards of Federalism: The Role of the States in the Composition and Selection of the National Government, 54 Colum. L. Rev. 543 (1954); Jesse Choper, Judicial Review and the National Political Process (1980).

33 See Donald H. Hadier, When Governments Come to Washington: Governors, Mayors, and Intergovernmental Lobbying (1974); Anne Marie Cammisa, Governments as Interest Groups: Intergovernmental Lobbying and the Federal System (1995); John Dinan, State Government Influence in the National Policy Process: Lessons from the $104^{\text {th }}$ Congress, 27 Publius 129 (1997). 
backed away. ${ }^{34}$ In an important study, Larry Kramer has suggested that political negotiation coordinated under the auspices of the national political parties has evolved into the single most important mechanism by which states influence the behavior of national officials. ${ }^{35}$ Through such means, state officials may head off legislation of which they disapprove before it is enacted, or obtain modifications of proposed national policies that eliminate or moderate provisions to which state officials object. As the Supreme Court observed more than twenty years ago: The effectiveness of the federal political process in preserving the States' interests is apparent ... in the course of federal legislation. On the one hand, the States have been able to direct a substantial proportion of federal revenues into their own treasuries in the form of general and program-specific grants in aid.... As a result, federal grants now account for about one-fifth of state and local government expenditures.... Moreover, at the same time that the States have exercised their influence to obtain federal support, they have been able to exempt themselves from a wide variety of obligations imposed by Congress under the Commerce Clause. For example, the Federal Power Act, the National Labor Relations Act, the Labor-Management Reporting and Disclosure Act, the Occupational Safety and Health Act, the Employee Retirement Income Security

34 Compare Garcia v. San Antonio Metropolitan Transportation Authority, 469 U.S. 528 (1985), with New York v. United States, 505 U.S. 144 (1992), and Printz v. United States, 521 U.S. 898 (1997). See also United States v. Lopez, 514 U.S. 549 (1995).

35 Larry Kramer, Putting the Politics Back into the Political Safeguards of Federalism, 100 Colum. L. Rev. 215 (2000). 
Act, and the Sherman Act all contain express or implied exemptions for States and their subdivisions. ${ }^{36}$

As this account suggests, the states have been able successfully to exploit their political influence in Washington to obtain many benefits and concessions from the national government. ${ }^{37}$

4. Withholding of Necessary Cooperation. Even where the national government has exercised its power in ways that states find objectionable, they often are not deprived entirely of the means to ameliorate what they perceive to be negative influences of that power on the state's citizenry. As the Framers anticipated, the successful invocation of national power sometimes requires the cooperation of state officials. ${ }^{38}$ In recognition of this requirement of intergovernmental cooperation, Congress has frequently structured national programs so as to delegate to state officials a crucial role in the implementation and enforcement of the programs. All of the largest and most costly non-military domestic national programs — social security, welfare, food stamps, and so on — delegate much of the responsibility for the day-to-day operation of the programs to the states. ${ }^{39}$ State responsibility for running these programs may include setting eligibility requirements, determining benefit levels, or enforcing compliance with

36 Garcia v. San Antonio Metro. Transit Auth., 469 U.S. 528, 552-53 (1985).

37 For a recent, sustained, and detailed account of how states have successfully used their power in this way, see John D. Nugent, Safeguarding Federalism: How States Protect Their Interests in National Policymaking (2009).

38 The Federalist, supra note 1, No. 27 (Hamilton), at 176-77.

39 See, e.g., 42 U.S.C. $\$ \S 601-604$ (establishing federal grants to states for welfare programs and delegating to states substantial discretion as to how to meet programmatic goals); 42 U.S.C. $\$ \$ 1397,1397$ a (establishing federal social security block grants and setting out goals states are to meet in administration of the grants). 
programmatic requirements, functions that require the exercise of a significant amount of official discretion. $^{40}$

When the national government grants states this kind of significant responsibility for implementing national initiatives, it often does so by establishing parameters that define the outer boundaries of state discretion. ${ }^{41}$ Nevertheless, within these boundaries, state officials may often have room to bend their implementation of national policy in ways that also serve state interests, even when those interests are opposed to successful implementation of the national program. ${ }^{42}$

Even more straightforwardly, states may simply refuse financial incentives offered by the national government to secure state cooperation. ${ }^{43}$ For example, New Hampshire has refused repeatedly to enact a mandatory seatbelt law, thereby forgoing a portion of its allocation of federal highway maintenance and construction funds. ${ }^{44}$ Nevada and Wisconsin for years sacrificed federal highway funds by refusing to lower their statutory threshold for drunken driving convictions to a blood alcohol level of 0.8 percent, in defiance of federal law requiring Law (1977). Bardach calls policy implementation "the continuation of politics by other means." Id. at 85.

41 See, e.g., Saundra K. Schneider and William G. Jacoby, Influences on Bureaucratic Policy Initiatives in the American States, 6 J. of Public Administration Research and Theory 495, 502 (1996).

$42 \quad$ According to one study, "Washington has had, and continues to have, tremendous difficulty in executing even relatively straightforward policies precisely because state and local governments enjoy such wide latitude in deciding how best to translate federal policies into action, or whether, in fact, to follow federal policies at all. The empirical evidence on this point is simply overwhelming." John J. DiIulio, Jr., and Donald F. Kettl, Fine Print: The Contract with America, Devolution, and the Administrative Realities of American Federalism 18 (1995). See also Margaret H. Lemos, State Enforcement of Federal Law, 86 N.Y.U. L. Rev. __ (forthcoming 2011).

43 South Dakota v. Dole, 483 U.S. 203 (1987). See Albert J. Rosenthal, Conditional Spending as a Regulatory Device, 26 San Diego L. Rev. 277 (1989); Calvin R. Massey, Etiquette Tips: Some Implications of "Process Federalism," 18 Harv. J. Law and Public Policy 175 (1995).

44 See Donn Tibbetts, Lift Seat-Belt Sanctions, Merrill Urges DOT Chief, Manchester Union Leader, Jan. 28, 1995, at A-1; Editorial, Buckled by Choice: The Useless Seatbelt Mandate, Manchester Union Leader, April 29, 2009. 
the adjustment. ${ }^{45}$ Kentucky abolished state vehicle emission standards, threatening its ability to meet federally mandated pollution limits, which would lead to the loss of nearly $\$ 2$ billion in federal highway funds. ${ }^{46}$

5. Recourse to Law. Another fully legal and formally recognized way in which American states influence policy-making by the national legislative and executive branches is by invoking the power of the national judicial branch against them. States have often had success suing the federal government in federal court over alleged abuses of national authority. In 1992, for example, New York successfully sued the United States in federal court, obtaining a ruling invalidating a portion of the federal Low-Level Radioactive Waste Policy Amendments Act of 1985 on the ground that one of its provisions exceeded national authority under the Commerce Clause. ${ }^{47}$ In subsequent years, federal courts have at the behest of states or state agencies invalidated numerous other federal statutes on similar grounds. ${ }^{48}$ In each of these cases, a federal court has held that some piece of national legislation exceeded the limits of enumerated national powers.

$45 \quad$ Ed Vogel, Lower Drunken Driving Standard Sought, Las Vegas Review-Journal, Mar. 7, 2001; Amy Rinard, State Pays for Its 0.10 Standard, Milwaukee Journal Sentinel, Apr. 21, 2002.

46 Tom Loftus, Patton Signs Bill Abolishing Vehicle Emissions Tests in Jefferson, Louisville (Ky.) Courier-Journal, Apr. 9, 2002.

$47 \quad$ New York v. United States, 505 U.S. 144 (1992).

$48 \quad$ For example, states have successfully persuaded federal courts to invalidate on sovereign immunity grounds numerous federal statutes creating private causes of action against the state. See, e.g., Bd. of Trs. of the Univ. of Ala. v. Garrett, 531 U.S. 356, 374 (2001); Kimel v. Florida Bd. of Regents, 528 U.S. 62, 91 (2000); Alden v. Maine, 527 U.S. 706, 759 (1999). Most recently, numerous states have joined in challenging recently enacted federal health care legislation, a centerpiece of the Obama Administration's policy commitments, as beyond the scope of national authority. See National Conference of State Legislatures, State Legislation and Actions Challenging Certain Health Reforms, 2010, Table 2, http://www.ncsl.org/?tabid=18906 (last visited Dec. 14, 2010). 


\section{B. SPain: Subnational Power in a Regime of DECENTRALIZATION BY SUFFERANCE}

\section{Constitutional Allocation of Power in Favor of the Central State}

The present Spanish Constitution was adopted in 1978 following the fall of the Franco regime. In response to fears in many quarters that the sudden easing of decades of central repression might quickly lead to a disintegration of a newly refounded, democratic Spanish state, the Spanish Constitution was drafted to create an extremely powerful and highly centralized national government - far more so than the government of the United States.

The Spanish Constitution begins with an emphatic statement of national identity. "National sovereignty," it proclaims, "belongs to the Spanish people, from whom all state powers emanate."49 "The Constitution," it goes on, "is based on the indissoluble unity of the Spanish Nation." ${ }^{50}$ Despite this fundamental commitment to a national model, the Spanish Constitution contains elaborate provisions authorizing a substantial degree of decentralization of power. Indeed, in many respects the Spanish Constitution looks very much as though it contemplates the creation of a federal-style state, albeit by different means than are ordinarily employed by most federations. The promise of these provisions, however, is undermined by a small number of key provisions that dramatically diminish the possibility of meaningful formal Spanish subnational autonomy.

Early on, in acknowledgment of Spain's long history of shifting regional power and its deep cultural diversity, the Spanish Constitution "recognizes and guarantees the right to

49 Spanish Constitution, Art. 1(2) (emphasis added). All citations are to the translation appearing at the official website of the Spanish Senate, http://www.senado.es/constitu_i/indices/consti_ing.pdf.

50 Id., Art. 2. 
self-government of the nationalities and regions of which it is composed." ${ }^{\prime 51}$ An entire chapter of the Constitution appears to make good on this promise by recognizing the "right to self-government" of Autonomous Communities (Communidades Autónomas), which it defines to include "bordering provinces with common historic, cultural and economic characteristics" and "provinces with a historic regional status." 52 Several sections follow this provision that, as in virtually every constitution drafted since the end of World War II, parcel out the various competencies of the national and subnational governments into those that are exclusively national, those that may be exercised exclusively by subnational units, and those that may in certain circumstances be exercised concurrently at both levels. ${ }^{53}$ On paper, the division of competencies is not weighted especially in favor of either national or subnational power, and to the casual reader probably does not look all that different from the division of competencies found in the constitutions of established federal states such as Germany or Austria.

Where the Spanish Constitution differs dramatically from standard European models of constitutional federalism, however, is in the mechanism it creates to devolve power to the Autonomies, one weighted heavily toward the central state. This is because neither the existence nor the powers of any Autonomous Community is guaranteed, or even recognized, by the Spanish Constitution. Rather, the Constitution delegates all decisions to recognize and empower Autonomous Communities entirely to the Spanish Parliament (Cortes Generales) as matters of purely legislative discretion. Thus, Section 144 provides: "The Cortes Generales

$\begin{array}{ll}51 & \text { Id. } \\ 52 & \text { Id., Art. 143(1). } \\ 53 & \text { Id., Arts. 148-150. }\end{array}$


may, .. . by an organic act . . . [a]uthorize the setting up of a Self-governing Community." 54 Although the provinces seeking recognition as an Autonomous Community in the first instance draft a Statute of Autonomy (Estatuto de Autonomía) for parliamentary consideration, ${ }^{55}$ Parliament is free to alter the proposed statute. ${ }^{56}$ Moreover, even though the Constitution expressly provides that an approved Statute of Autonomy "shall be the basic institutional rule of each Self-governing Community"57 - that is, shall function as a subnational constitution - it also provides that any and all amendments to the Statutes must be approved by the Spanish Parliament. ${ }^{58}$

In giving the central government virtually unlimited power to approve both the creation of Autonomous Communities and their assumption of constitutionally authorized powers of self-governance, the Spanish Constitution departs significantly from the most common model of constitutional federalism. In federal states, the authority of subnational units to govern themselves, and the powers they may exercise, are typically provided by the constitution, not by the national legislature. Even where the legislature retains authority to recognize new self-governing subnational units, as in the United States, ${ }^{59}$ or to rearrange the boundaries of

\footnotetext{
54 Id., Art. 144(1) (emphasis added).

55 Id., Art. 151(2)(ii).

56 Id., Art. 151(2)(v). However, no such alteration will become effective without subsequent ratification by a popular vote of the relevant subnational populace.

$57 \quad$ Id., Art. 147(1).

$58 \quad$ Id., Art. 147(3).

$59 \quad$ U.S. Const. Art. IV, $§ 3$.
} 
existing ones, as in Germany ${ }^{60}$ subnational units once recognized retain their autonomy and powers independently of the wishes or actions of the central government. The Spanish model, in contrast, more closely approximates what Americans will recognize as the Dillon's Rule model of local home rule. Under this model, localities owe their existence, along with each and every power they are permitted to exercise, to the discretion of the central legislature - a model long understood in the U.S. to make local power almost entirely dependent on central beneficence. ${ }^{61}$

The constitutional decision to make the possibility and scope of subnational self-governance dependent on the central state is weighted even further in favor of the state by the fact that the Spanish Constitution provides Autonomous Communities no formal role in the official decision making processes of the Spanish government. In many decentralized states, the national government is structured to include some venue in which subnational units may officially voice their interests as autonomous representatives of constituent units of the nation. ${ }^{62}$ In the United States, for example, the Senate provides states with such a forum.

In Spain, by contrast, Autonomous Communities are largely excluded from the national councils of governance. Although the Spanish Parliament is bicameral, and includes a chamber denominated a "Senate," ${ }^{63}$ the Spanish Senate differs from those found in bicameral federal states. The Spanish Constitution defines the Senate as "the House of territorial

60

61 Osborne M. Reynolds, Jr., Local Government Law 167-80 (3d ed. 2009).

62 E.g., U.S., Germany, Canada, Switzerland, Austria or Belgium. See generally Watts, supra note 15 , at $92-97$.

63 Spanish Constitution, Art. 69. 
representation." 94 The territories represented, however, are not autonomously self-governing subnational units - they are not, in other words, the Autonomous Communities. They are instead "provinces," which are by definition subunits of territories that may seek recognition as Autonomous Communities. ${ }^{65}$ In the United States, this arrangement would correspond to one in which the U.S. Constitution guaranteed senatorial representation to counties rather than states. The Spanish Constitution does go on to authorize each Autonomous Community to designate one senator, plus an additional senator for each million inhabitants it contains. ${ }^{66}$ However, the structure of these constitutional rules ensures that senators who directly represent the Autonomous Communities as Communities are far outnumbered by those representing individual provinces. As a result, not only must Autonomous Communities seek approval from the Spanish Parliament every time they wish to create or amend their Statutes of Autonomy, but they also have no official voice in formal decision making processes by which Parliament deals with such requests.

\section{Development of Extraconstitutional Avenues of Influence}

It seems clear from the foregoing analysis that formal national power in Spain far outstrips subnational power, and that the degree to which national power predominates over subnational power in Spain far exceeds the degree to which it does so in the United States. Nevertheless, even in an environment that seems extremely hostile to the exercise of subnational influence over policy-making at the national level, the Spanish Autonomous Communities have

$\begin{array}{ll}64 & \text { Id., Art. 69(1). } \\ 65 & \text { Id., Art. 143(1). } \\ 66 & \text { Id., Art. 69(5). }\end{array}$


begun to develop methods of doing just that. These efforts have been slow. Progress has been unsystematic. Some of the mechanisms for asserting subnational influence are rudimentary and undeveloped. But Spain's new constitutional regime is young, and we think it is fair to say that the groundwork is already being laid to create a system of national-subnational relations that is much more complex, more nuanced, and more balanced than the lopsided allocation of power described above. Under its present constitutional regime, Spain may never be a genuine federal state. But it does not follow that Spain cannot be a meaningfully decentralized state in which subnational units enjoy a measure of real autonomy within their own borders and real influence in Madrid.

In this section, we briefly describe a few leading examples of emerging mechanisms that Spanish subnational units have been developing to augment the limited autonomy and influence that the formal provisions of the Spanish Constitution accord them.

1. Supplication. Under the Spanish Constitution, the most direct method by which Autonomous Communities can gain a greater measure of autonomy and self-governance is simply and straightforwardly by asking for it. In principle, the Spanish Constitution holds out to the Autonomies the possibility of assuming a fair amount of power. Granting such requests lies within the complete discretion of Parliament, and it therefore need not grant Autonomous Communities all or even any of the autonomous power they seek. On the other hand, it may do so if it wishes. The trick therefore lies in obtaining the necessary parliamentary approval.

In many cases - indeed, in most - Parliament has seen fit to exercise its discretion beneficently. For example, Statutes of Autonomy proposed by the Autonomous Communities of Valencia, the Balearic Islands, Aragon, Castilla León, Galicia, and Andalusia passed easily 
and without controversy. ${ }^{67}$ On the other hand, although the central state may devolve power through an exercise of beneficence, such power is held insecurely; what has been unilaterally granted may be unilaterally revoked.

2. Political Influence. A highly significant avenue that Spanish subnational units have employed to protect their interests and to influence national policy making is political influence exercised through the medium of political parties. Spain is a multiparty democracy ${ }^{68}$ in which about a dozen parties are regularly able to elect at least one member of the parliamentary lower chamber, the Chamber of Deputies. Two large and powerful parties of nationwide scope and appeal tend to predominate: the Socialist Workers' Party (Partido Socialista Obrero Español, or PSOE), the main party of the left; and the People's Party (Partido Popular, or PP), the main party of the right. Despite their size, however, neither party typically is able to command an outright majority in the Chamber, meaning that the major parties frequently must form coalitions with minor parties to govern or to enact and defeat specific pieces of legislation. Many of the largest potential coalition partners are parties of primarily regional appeal. These include the Republican Left of Catalonia (Esquerra Republicana de Catalunya, or ERC); Convergence and Union (Convergència i Unió), a coalition of two Catalan parties; the Basque Nationalist Party (Euzko Alderdi Jeltzalea, or EAJ); the Canarian Coalition

67 The parliamentary votes were as follows: Aragon, 283-0, 10 abstentions. Diario de Sesiones del Congreso de los Diputados, num. 205, Oct. 3, 2006. Castilla Leon, 294-0, 6 abstentions. Id., num. 247, April 17, 2007. Balearic Islands, 313-0, 6 abstentions. Id., num. 197, September 12, 2006. Valenciana, 326, 294-32. Id., num. 148, February 9, 2006. Andalucia, 308-0, 2 abstentions. Id., num. 210, November 2, 2006. Compare the vote on the Catalonian amendments: 189-154, 2 abstentions. Id., March 31, 2006.

68 Election to the lower house of Parliament is by a semi-proportional method in which each province elects a number of representatives prescribed by law, but elections within each province are proportional. Spanish Constitution, Art. 68. 
(Coalición Canaria, or CC); and the Galician Nationalist Bloc (Bloque Nacionalista Galego, or BNG) - all parties based primarily in specific self-governing subnational communities. ${ }^{69}$

This arrangement creates two potentially important opportunities for subnational influence over national policy. First, of course, where a national governing coalition includes a party with a strong base in an Autonomous Community, the interests of that Autonomous Community must be taken into account if the dominant member of the coalition is to bring along its partners. Second, where parliamentary representation is closely divided, the dominant parties must bring along their own members, including those members elected from Autonomous Communities that might have particular interests they wish to advance within the major parties themselves. In both cases, it may be possible for representatives elected from the Autonomies to strike deals favorable to the interests of subnational power in general, or their individual constituencies in particular.

A stark example of this phenomenon is the drastically different treatment accorded by Parliament to requests by Catalonia and the Basque Country for approval of amendments to their respective Statutes of Autonomy. In 2005, both Autonomies formally requested that Parliament approve significant amendments to their Statutes of Autonomy. For reasons that will be described in more detail below, both proposals were perceived by the central state as controversial and threatening to national unity. In the end, however, Parliament approved the Catalan amendments but not the Basque amendments, which it continues to resist. ${ }^{70}$ The decisive difference was that the same political party, PSOE, governed in both Catalonia and in

69 The other significant minor party is the United Left (Izquierda Unida, or IU), a coalition centered around the Spanish communist party.

$70 \quad$ See infra Parts IV.B.2 and 3. 
Madrid, and the central government needed the support of the Catalan minor parties (CIU or ERC) in the Chamber of Deputies to accomplish the national political agenda. In the Basque case, in contrast, the central government (PSOE) did not need support in the Chamber of Deputies of the Basque political parties (PNV/EA). As a result, Catalonia obtained a new Statute of Autonomy, but the Basque Country has not.

3. Popular Political Mobilization. Another method for achieving political influence that is much more widely used in Spain than in the United States is mass popular political mobilization - i.e., public demonstrations. Massive demonstrations and boycotts have been used on many occasions to generate pressure to affect the political agendas of the central state or the Autonomous Communities. These events are frequently orchestrated by political parties as a means of obtaining what they cannot achieve through the exercise of formal political power, but may also be organized by private groups with political or religious agendas.

An example of how popular political mobilization can be utilized by subnational units to influence national policy is the case of the "Papers of Salamanca," a conflict that pitted the Spanish State against the Generalitat of Catalonia. The dispute related to the ownership of certain documents, files, pictures, and personal letters held in the General Archive of the Spanish Civil War housed in Salamanca. The main collection of the Archive was assembled at the conclusion of the Civil War by the Delegación del Estado para la recuperación de documentos, located in Salamanca, in the Autonomous Community of Castilla y León. This government agency gathered up documents, pictures, and effects that the Franco troops had obtained from the different fronts of the Civil War and deposited them in Salamanca. ${ }^{71}$

Historia.html.

See official website of the Archivo, http://www.mcu.es/archivos/MC/AGC/Presentacion/ 
Since the end of the War, families and other individuals in Catalonia and Valencia, as well as the Catalan government itself, have asked for the return of these materials to their original owners. After numerous claims and failed negotiations, the Spanish Government in 1995 agreed to the return to Catalonia of papers claimed to be of Catalan origin and ownership. Less than two weeks after execution of this agreement, a massive public demonstration in Salamanca protested movement of the papers to Catalonia. In sympathy with these demonstrations, the Mayor of Salamanca went so far as to order the municipal police to guard the entry to the Archive. In the face of this public pressure, the Spanish Government backed down, and decided instead to convene a commission of experts to study the question of ownership. Proceedings dragged on until 2002 when, in consideration of the recommendations of a badly divided commission, the Spanish Government decided that all documentation prior to 1936 should remain in Salamanca. Actual return of the later documents has since been tied up in court. ${ }^{72}$

Interestingly, the use of popular mobilization is not confined to efforts by the periphery to influence the center; sometimes interests that support political positions that are held by a national majority, and which are well represented in Parliament, will organize demonstrations against minoritarian policies or assertions of power by individual Autonomous Communities. For example, when the Catalan Parliament (Generalitat) approved the amendment to the Catalan Statute of Autonomy mentioned above, several Spanish associations and media organizations

\footnotetext{
Accounts of the dispute can be found at the website of the Salamanca town government, http://web.aytosalamanca.es/archivo/presentacion.jsp, and the site of the Commissió de la Dignitat, http://www.comissiodeladignitat.cat/l-entitat/angles.
} 
invoked the tactics of popular mobilization to urge a boycott of Catalan products for the express purpose of inducing a change in Catalan policy. ${ }^{73}$

4. External Influences. One avenue by which Spanish subnational units may influence the central state that is entirely unavailable to subnational units in the United States is by appealing to institutions outside the state that are able to exercise influence within it. By far the most significant of these external institutions are the European Union and the European Court of Human Rights (ECHR). For example, the Basque Country has sued the Spanish State in the ECHR on two occasions in an attempt to reverse disliked policies of the Spanish government. In one case, Basque individuals and a Basque political party sued Spain over a law that banned a Basque political party, and in another case the Basque Government sued the Spanish State to invalidate a decision of the Spanish Constitutional Court holding that the Basque government lacks authority to put a referendum to Basque voters. ${ }^{74}$

In addition to the ECHR, Autonomous Communities have occasionally appealed to the European Parliament. For example, in 2007, in response to petitions received from numerous individuals, private groups, and the Autonomous Communities of Madrid and Andalusia, the European Parliament's Committee on Petitions undertook an investigation of coastal and urban development policies in the País Valencià. After a visit to the region and a wide-ranging investigation, the Committee issued a report harshly critical of development policies applied in the region:

73 A Google search of "boicot productos catalanes" turns up dozens of sites promoting such a boycott.

74 The relevant cases are Herri Batasuna vs. Spain, 25803/04; Batasuna vs. Spain, 25817/04, num. 103; Etxeberria and 3 others vs. Spain, 35579/03, num. 103; Nafarrako Autodeterminazio Bilgunea vs. Spain, num. $35626 / 30$. 
The Petitions Committee remains concerned and deeply troubled as a result of the persistent and long-standing denial of the legitimate rights of many European citizens in Spain, most notably in the Valencian Region, to their land and their homes. They have become the collateral victims of many rampant urbanisation programmes founded upon legislation which provides privilege and wealth for the urbaniser and which denies individuals their very integrity.

In a large number of documented cases town councils have concocted urban development plans less because of their real requirements related to population growth and tourism, more because of what often appears as their greed and avarice.... In no other EU country are citizens' rights to their property abused in this way or to this extent, and no petitions from any other EU country on such matters have been received. ${ }^{75}$

The Committee concluded by calling for further action by the European Commission and by Spanish regional authorities.

Another kind of supranational institution to which Spanish subnational units have from time to time appealed when thwarted by the central state are private international federations. Such appeals have been especially successful in the area of international sports competition. As a matter of law, Spain does not permit Basque and Catalan teams to compete in international competitions, a decision that reverses a long tradition of such teams appearing as representatives of their historical communities. The Basque and Catalan Autonomous Communities protested enactment of the law, and later challenged it in the Constitutional Court, which upheld the ban in

\footnotetext{
75 European Parliament, Committee on Petitions, Report on the Fact-finding Visit to Madrid, Valencia, Andalucia, Feb. 27-Mar. 3, 2007, pp. 2-3. See http://www.europarl.europa.eu/document/activities/cont/ 200801/20080131ATT20224/20080131ATT20224EN.pdf.
} 
a 1998 decision. ${ }^{76}$ Since then, Catalan sports federations have taken their case directly to international sporting organizations and federations, where they have enjoyed considerable success, achieving recognition - and the right to compete as Catalan teams alongside Spanish teams - in bowling, rowing, racquetball, korfball, pitch and putt, twirling, Australian football, and futsal. ${ }^{77}$

5. Violence and Defiance. Finally, although resort to violence, or defiance backed by the threat of violence, is used sparingly in the United States, it is essentially unheard of in Spain as a tool of official policy. The European experience of war in general, and the Spanish experience of civil war in particular, is simply too fresh and too frightening to permit government officials recourse to this avenue of influence. Threats of violence by subnational officials would be ill received not only by the central government, but by subnational populations as well. ${ }^{78}$

\section{Conclusions}

It is of course hazardous to draw conclusions from parsimonious data, and here we have examined a comparatively small number of examples in only two countries. Still, with this caution in mind, we think what we have shown is sufficient to permit us to suggest some very tentative conclusions that warrant further study in other settings. February 9, 1999.

Federation.

$$
\text { E.g., decision of T.A.S, April 23, 2008, in Catalan Federation of Bowling vs. Spanish Bowling }
$$

78 This is not to say that violence - even overtly separatist violence - has not played a role in Spanish political life. Nevertheless, such violence and the threat of it have been employed by private, unofficial groups from which governing authorities have been at great pains to distance themselves. 
First, subnational actors in federal systems seem capable of developing an extensive and in many cases creative array of extraconstitutional methods to influence national power. Federalism in the United States was designed to be strongly decentralized, but over time evolved into a much more strongly national system. Yet despite the pragmatic and, increasingly, formal constitutional dominance of American national power, the states have nonetheless developed, and continue to maintain, a broad pallette of methods by which to advance their interests in the processes of national decision making. Spain's initial constitutional allocation of power tilted even more decisively toward the central state. Yet despite the presence of an explicit, highly forcing constitutional structure, Spain's formal centralization has not in practice inhibited the development of a relatively robust system of subnational decentralization based on meaningfully mutual checking of power.

Initial asymmetries of power constructed by constitutional design (or, in the American case, by constitutional evolution), we therefore tentatively conclude from these examples, can thus be altered by informal arrangements and workarounds, moderating any dangers of instability posed by ill-advised or poorly executed baseline constitutional endowments. It follows that a vertically symmetrical initial constitutional allocation of power may be less important than the Madisonian model predicts because of the ability of official actors to develop significant extraconstitutional methods of mutual influence.

Second, in both the United States and Spain - two very different political environments constituted by very different regimes of power sharing - ostensibly weak subnational units have managed to develop extraconstitutional methods for protecting their interests and influencing national policy that are reasonably effective at least some of the time. This does not mean that 
national power does not and will not continue to predominate in both nations. It does mean, however, that the dominance of national power is not nearly as complete as it may seem from a reading of the constitutions themselves or their interpretations by national courts. We suspect that close investigation in other nations of how subnational power is exercised on the ground will reveal a host of examples similar to those described here.

Despite their different constitutional structures and substantially different allocations of national and subnational power, then, the conditions for sustainable decentralization seem to have evolved in both the United States and Spain. Nevertheless, although sustainable decentralization seems well entrenched in the United States, in Spain it is threatened. As we have shown, however, this threat does not arise from the obvious source: a constitutional allocation of power that tilts heavily in favor of centralization. It arises instead from the asymmetrical relations that Spanish subnational units enjoy with the central state. We turn now to this more serious problem.

\section{Asymmetry in Subnational Relations to National Power}

\section{A. The Assumption of Horizontal Symmetry in Contestatory Federalism}

A frequently overlooked yet highly important assumption of the Madisonian conception of contestatory federalism is that the American states would fundamentally share a deep, common interest in the restraint of national power. The American Framers did not, of course, contemplate that the states themselves would exhibit any particular uniformity; they understood from their own experience that the states would likely diverge in size, population, resources, history, customs, legal traditions, and preferences regarding the details of self-governance. 
Indeed, the Framers expressly relied on an anticipated diversity of interests within the states in justifying the large geographic extent of the proposed new nation. ${ }^{79}$

Nevertheless, the Framers did believe strongly, even axiomatically, that all American states, whatever their other characteristics, would possess essentially uniform interests with respect to the national government. First, the Framers evidently thought it perfectly clear that all the states should, and would, exhibit a healthy fear of the national government. Although members of the founding generation differed on the question of how much power ought ideally to be allocated to the central government, they shared the belief that at some point the degree to which power is centralized can become excessive, raising the danger of central tyranny. ${ }^{80}$ This view, they clearly believed, would be shared by the states and would form a reliable and universal foundation for state policy decisions respecting the national government.

Second, the Framers assumed that the states, because they feared excessively centralized power, would share a common interest in ensuring that the national government be prevented from accumulating a dangerous measure of power. ${ }^{81}$ Finally, the Framers assumed that the states would act cooperatively rather than competitively should efforts become necessary to hold the power of the national government within constitutional limits. If threatened, in other words, the states would join forces to make common cause against the national government:

It may safely be received as an axiom in our political system that the State governments will, in all possible contingencies, afford complete security against

79 The Federalist, supra note 1, No. 10 (Madison).

$80 \quad$ Id., No. 47 (Madison).

81 The Federalist, supra note 1, No. 46 (Madison), at 298 ("ambitious encroachments of the federal government, on the authority of the State governments, would not excite the opposition of a single State, or of a few States only. They would be signals of general alarm"). 
invasions of the public liberty by the national authority. Projects of usurpation cannot be masked under pretences so likely to escape the penetration of select bodies of men, as of the people at large. The legislatures will have better means of information. They can discover the danger at a distance; and possessing all the organs of civil power and the confidence of the people, they can at once adopt a regular plan of opposition, in which they can combine all the resources of the community. They can readily communicate with each other in the different States, and unite their common forces for the protection of their common liberty.... If the federal army should be able to quell the resistance in one State, the distant States would be able to make head with fresh forces. The advantages obtained in one place must be abandoned to subdue the opposition in others; and the moment the part which had been reduced to submission was left to itself, its efforts would be renewed, and its resistance revive. ${ }^{82}$

On this view, the states will respond to the threat of central tyranny not by competing with one another for the favor or mercy of a dangerous national government, but by rising in unison against a threat to any of them. This was, indeed, the model of resistance to central authority that the Framers knew from the Revolution. The various colonies may have had different tastes for engaging in open resistance to Great Britain, but once the course of events became clear, each colony stood shoulder to shoulder alongside the others.

This kind of symmetry of interests and motivations is, it turns out, a critical assumption underwriting the Madisonian model of contestatory federalism. If, in times of crisis, subnational governments do not stand together against national power, their ability successfully

82 Id., No. 28 (Hamilton,) at 181. 
to resist it will be badly compromised. If some subnational units attempt to pursue their own interests unilaterally, either by seeking favor with the national government by betraying one another, or by adopting positions of neutrality in national-subnational conflicts, or by affirmatively allying themselves with the national power against other subnational units, the ability of the national government to control the course of events will be greatly strengthened. Over the long run, such behavior risks undermining severely the ability of subnational governments to resist future encroachments on their interests by the national government, either individually or collectively.

In the United States, the Madisonian assumption of symmetry in subnational relations to the national government has held up well. American states do not typically compete with one another for the favor of the national government, and the states seem consistently to have perceived their own interests against Washington as common interests shared generally by all the states. $^{83}$ To be sure, representatives of the states in Congress may compete among one another for scarce federal benefits - the siting of military bases or government offices, for example, or allocations of public works funding. Members of Congress from different states also frequently compete with one another on questions of policy that have ramifications for the welfare of individual states or regions - whether, for example, federal policy should support rural or urban areas, or agricultural or industrial interests, and so on. But these competitions are never understood as competitions among states for the favor of the national government; they are instead understood as competitions among national constituency groups and interests. A state

83 One small but suggestive indication of this is the common practice of states supporting one another in litigation before federal courts such as through intervention or the filing of jointly prepared amicus briefs. See Michael E. Solimine, State Amici, Collective Action, and the Development of Federalism Doctrine (October 15, 2010), U of Cincinnati Public Law Research Paper No. 10-32, available at http://ssrn.com/abstract=1694081. 
seeking national investment is not offering its friendship and support as a sovereign to the central state, but is merely engaged in a collective politics of distribution, a kind of politics that in fact contributes to the perception that all states stand on a footing of equality before national power. As a result, in the United States, when subnational governments do act to check national power, they nearly always do so in a way that is uniform and collective. ${ }^{84}$

Finally, on those rare occasions when American states do engage in rivalries in their capacity as autonomous sovereigns, those disputes are typically resolved as a matter of law in the courts - not as a matter of politics in Congress. Under Article III of the U.S. Constitution, the Supreme Court has original jurisdiction over disputes between states acting in their sovereign capacity. The Court has exercised this authority to resolve disputes between states over the location of borders, jurisdiction over taxable resources, and rights in natural resources ${ }^{85}-$ the very kinds of disputes that in other times and places might be resolved through highly politicized negotiation brokered by the central state. Moreover, the U.S. Constitution affords states few opportunities for appealing to Congress to intervene in such disputes, thereby reducing the risk that one state will appear to enjoy greater favor with the central government than another. ${ }^{86}$

84 The U.S. Constitution actually contains some provisions that prevent the central government from playing favorites among the states. See, e.g., Art. I, § 9, cl. 4 ("No Capitation, or other direct, Tax shall be laid, unless in Proportion to the Census or Enumeration ..."); cl. 6 ("No Preference shall be given by any Regulation of Commerce or Revenue to the Ports of one State over those of another").

85 See, e.g., Rhode Island v. Massachusetts, 37 U.S. 657 (1838) (boundary dispute); California v. Texas, 457 U.S. 164 (1982) (whether Howard Hughes was at his death a domiciliary of California or Texas); Kansas v. Colorado, 206 U.S. 46 (1907) (diversion of river water).

86 The great counterexample is of course the American Civil War, but this involved a breakdown rather than an implementation of the constitutional order. Within the constitutional order, the most significant exception arises when Congress considers legislatively altering the size of the House of Representatives; then states compete squarely in the political arena over the relative sizes of their delegations. See, e.g., Charles W. Eagles, Democracy Delayed: Congressional Reapportionment and Urban-Rural Conflict in the 1920s (1990), ch. 3. 


\section{B. Spain: The Problem of Horizontal Asymmetry in Relations with the Central State \\ 1. Subnational Disputes over the Scope of Subnational Autonomy}

In sharp contrast to the American case, in Spain the tools of extraconstitutional influence have been developed and from time to time used asymmetrically by the various Autonomous Communities. Whereas some Autonomous Communities seem to feel a strong need continually to develop and exploit extraconstitutional methods for influencing exercises of national power, others do not. One reason for this diversity seems to be that not all Autonomies fear the Spanish central state in the manner anticipated by the model of contestatory federalism. On the contrary, the Autonomies seem to diverge substantially in the degree to which they feel some sense of solidarity with, or indeed ownership of, the Spanish state.

Moreover, contrary to the assumptions of the Madisonian model of contestatory federalism, some Spanish Autonomous Communities seem to fear other Autonomous Communities more than they fear the central state itself. Consequently, Autonomies such as Andalusia and Castilla La Mancha, which enjoy close and comfortable relationships with Spain, have far less cordial relationships with Autonomies such as the Basque Country, Catalonia, and Galicia, which they seem to believe pose a greater long-term threat to their welfare than the national government. Spanish subnational units thus disagree regularly about perhaps the single most important characteristic of any system of decentralized power: whether and to what extent autonomy and power should be devolved from the central state in the first instance.

As a result, the Autonomous Communities sometimes make very different choices about how to use whatever kinds of influence with the national government they may possess. Some Autonomies use their influence mainly to advance policies that they support for the direct benefit 
of their own populations. Others, however, sometimes use their influence not so much to advance directly their own interests, but to induce the national government to control other Autonomies that they perceive as threatening, or to improve their position vis à vis other Autonomies with which they understand themselves to be in competition. Thus, in contradiction of a basic condition of the Madisonian model, Spanish subnational units will from time to time exercise their autonomous power and influence in ways that are not calculated to advance the interests of all autonomies collectively against the central state. This in turn creates conditions conducive to a potentially debilitating failure of successful decentralization: the central state playing favorites among competing subnational units. Some examples will help to illustrate this phenomenon.

1. Competition among Autonomies: Café para todos. In one of its healthier manifestations, rivalry among regions led to a somewhat comical competition to be recognized first as Autonomous Communities (in 1978), and then as "historical nationalities" under the Spanish Constitution. Under the process contemplated by the 1978 Constitution, three regions of Spain with claims to distinctive national identities based on history, language, and culture Catalonia, the Basque Country, and Galicia - were granted a substantial degree of autonomy under a fast-track procedure. ${ }^{87}$ Even before the Spanish Constitution was approved, however, other regions with perhaps less well-grounded claims to recognition as distinctive nationalities began to assert a right to similar treatment. These others, when presenting Statutes of Spanish Constitution, Transitional Provisions, Art. 2. 
Autonomy for approval to Parliament, included provisions claiming nationality status. ${ }^{88}$ This development was eventually dubbed "café para todos" (coffee for everybody) by its critics.

We deem this a relatively healthy manifestation of competition among Autonomous Communities because, although it grew from a distrust or suspicion among subnational units, it manifested itself in positive claims by those units for more and parallel autonomy from the central state. Thus, subnational units presented a relatively united front in their dealings with the central state. This has not, however, always been the case.

2. Selective Subnational Opposition to Assumption of Competencies. One arena in which a more destructive kind of competition among Autonomous Communities has arisen concerns the content of the various Statutes of Autonomy. The Statutes of Autonomy, it will be recalled, serve as subnational constitutions for the Autonomous Communities, and one of the most important functions of these documents is to serve as the vehicle by which Autonomies formally adopt competencies that the Spanish Constitution authorizes them to assume. In the first round of approval of the various Statutes of Autonomy, the Autonomous Communities generally did not adopt all of the powers available to them, and in subsequent rounds of proposed amendments, many of the Autonomies have therefore sought to adopt additional competencies from the constitutionally authorized list.

From time to time, some Autonomies have reacted very differently to proposals by various Autonomous Communities to amend their Statutes of Autonomy in similar or identical ways. In some of the more extreme cases, Autonomies have taken legal action to oppose amendments in one Autonomy that they have not opposed when proposed by others.

88 E.g., Statute of Autonomy of Andalusia (1982), Art. I; Statute of Autonomy of Castile y Leon, Preamble. 
For example, after an arduous political process, Catalonia in 2006 successfully obtained parliamentary approval of extensive amendments to its Statute of Autonomy. ${ }^{89}$ The amendments included provisions dealing with nationality and subnational identity, historical rights, criminal law enforcement, assumption of competencies, relations with the European Union, and access to the European Court of Justice, among many others.

Shortly after Parliament approved the amendments, the Autonomous Communities of Valencia, Murcia, la Rioja, the Balearic Islands, and Aragon, along with the Partido Popular, the political party governing in most of these Autonomies, filed suit in the Spanish Constitutional Court challenging the constitutionality of thirty different provisions of the Catalan amendments. $^{90}$ At the same time, however, many of the same provisions of the Catalan Statute that were challenged in the lawsuit also exist in the Statutes of Autonomy of Aragon, Andalusia, and Valencia without provoking either comment or opposition. ${ }^{91}$

89 Diario de Sesiones del Congreso de los Diputados, March 31, 2006. A detailed account of these events can be found in César Colino, Constitutional Change without Constitutional Reform: Spanish Federalism and the Revision of Catalonia's Statute of Autonomy, 39 Publius 262 (2009).

90 Recurso de inconstitucionalidad num. 8045-2006, Partido Popular vs Ley Organica 6/2006 de Reforma del Estatuto de Autonomia de Catalunya; Recurso de inconstitucionalidad num. 8675 -2006, Defensor del Pueblo vs. Ley Organica 6/2006 Reforma del Estatuto de Autonomia de Catalunya; Recurso de inconstitucionalidad num. 9501-2006 Comunidad Valenciana vs. Ley Organica 6/2006, Reforma del Estatuto de Autonomia de Catalunya; Recurso de inconstitucionalidad num. 9568-2006, Comunidad Autonoma de Baleares vs. Ley Organica 6/2006 de Reforma del Estatuto de Autonomia de Catalunya; Recurso de inconstitucionalidad num. 9491-2006, Comunidad Autonoma de Aragon vs. Ley Organica 6/2006, de Reforma del Estatuto de Autonomia de Catalunya. On June 28, 2010, the Constitutional Court issued a 400-page decision invalidating some of these provisions and imposing narrowing constructions on many others. STC 31/2010, de 28 de junio. The decision prompted Catalan President José Montilla to call for a massive public demonstration, which took place on July 10, 2010. An English translation of an analysis of the decision prepared by a committee reporting to the Catalan Generalitat may be found at http://www10.gencat.cat/drep/binaris/Informe\%20STC_eng_tcm112-133021.pdf.

$91 \quad$ Albert Lamarca and Vanessa Casado, 391 Comparativa entre les reformes dels Estatuts d'autonomia de Catalunya i d'Andalusia, Indret Revista anààlisi de dret 1 (Nov. 18, 2006). Available at http://www.indret.com/pdf/391.pdf. 
In a separate action in the Constitutional Court, Valencia sued to invalidate an amendment to the Catalan Statute of Autonomy assuming competence for the planning, construction and exploitation of hydraulic projects. ${ }^{92}$ Under this provision, Catalonia assumed responsibility for "waters that belong to intra-community hydrographic basins." 93 In contrast, when Aragon in 2007 adopted an identical provision assuming competence over internal waters, ${ }^{94}$ Valencia took no action, and indeed has never protested.

In a decentralized system of government, in which by hypothesis national power must be counterbalanced by adequate subnational power - and must be accompanied by a degree of autonomy adequate to use it independently on behalf of the interests of the subnational population - these kinds of action bear obvious risks. Normally, one would expect all subnational units to have virtually identical interests in the range and breadth of the competencies that may constitutionally be exercised by any subnational unit. Such decisions address the theoretical limits of permissible subnational power, and presumably all subnational units have an equivalent interest in seeing that the scope of their potential powers is interpreted as broadly as possible.

This is not to say that a subnational unit should in every set of circumstances wish to wield power to which it may potentially resort. Not all problems are best addressed at the subnational level, and there is no theoretical objection in any system of decentralized power to the cooperative exercise of authority at the national and subnational levels. Thus, in some or even many circumstances subnational units might be well advised to refrain from exercising

92 Spanish Constitution, Section 148(1)(x); Statute of Autonomy of Catalonia, Art. 117.

93 Statute of Autonomy of Catalonia, Art. 117.

94 Statute of Autonomy of Aragon, Art. 72. 
power that they possess. But it is quite another thing for a subnational unit to take the position that the assumption of a power by another subnational unit is not one that constitutionally may be exercised by any subnational unit, or by particular subnational units out of many. ${ }^{95}$ The pursuit of such a strategy by Valencia, Murcia, la Rioja, the Balearic Islands, and Aragon does not weaken Catalonia alone; it bears the potential to weaken all the Autonomous Communities collectively in their relation to the central Spanish state. The risk inherent in this strategy is all the more striking because of the drastic tilt of the constitutional balance of power in favor of the central Spanish state, and the fact that the central state has been a proven source of danger in the very recent past. The only possible explanation for such behavior is that these Autonomies distrust some Autonomous Communities not only more than they distrust Spain, but more than they distrust other Autonomies. This is a degree of distrust that seems potentially detrimental to the long-term success and stability of Spanish decentralization.

\section{Lack of Institutions of Collective Subnational Influence}

Clearly, many factors contribute to the rivalry among Spanish subnational units, and among these are real and legitimate differences among the Autonomous Communities

This phenomenon is thus distinct from a common one in the United States (and doubtless in many other federal nations) where the asymmetrical distribution among states of certain kinds of interests prompts different political responses to the same stimulus. In the U.S., for example, national policy concerning water, grazing, or national lands often triggers very different reactions from western states than it does in the east. Some states might well be indifferent to national policy decisions in which others take a keen interest, or states might divide in their judgment about the soundness on the merits of particular national policy decisions. But policy disagreement among the states is a very different matter from disagreement over the proper distribution of state and national authority, and it does not follow from one state's support for congressional resolution of a policy dispute against the preferences of another that the state thereby denies any claim of any other state to some specific measure of constitutional power or autonomy. If there are situations in the United States in which some states deny the validity of power or autonomy claims by others, they are surely exceedingly rare compared to the situations in which states join in asserting such claims against national power. Moreover, in the Spanish examples recounted in the text, the assumption of the contested powers by Autonomous Communities had already been authorized by the Spanish Constitution, making Autonomy-level opposition to their adoption even more puzzling. 
themselves, including divergent historical, cultural, and linguistic considerations. However, unlike many other federal states, Spain lacks institutional arrangements that might help ameliorate inter-Autonomy rivalries and channel assertions of subnational autonomy and power in more productive ways.

Perhaps surprisingly, there seems to be no tradition in Spain of generally shared subjective feelings of collective opposition to central power and tyranny. Throughout the long course of Spanish history, there has never been a "Spain" in which all regions were treated equally by the central state, or in which they equally feared it. From 1492 until 1712, Spain was constituted of different political entities enjoying varying degrees of mutual independence. After the War of Spanish Succession, which concluded in 1714, the Crown of Catalonia and Aragon lost its political and economic independence in favor of Castilla. The Basque Country, in contrast, because it supported the winning side, continued for a time to enjoy substantial autonomy. ${ }^{96}$ Thus, the origins of present-day Spain are based to some degree on the military superiority of one nation over another and the shifting fortunes of allies of one contestant or another in nationwide and European power struggles. Even in recent history, moreover, different regions experienced the rule of the Spanish Republic of 1936 and the dictatorship of Franco differently, with some winners and losers, again working against the development of a unified attitude among the regions toward the central state.

Against this background, and perhaps in part because of it, present-day Spanish political intercourse has failed to produce institutional frameworks in which Autonomous Communities might work together, cooperatively, either against or in concert with national power. We have already mentioned the absence of a legislative chamber (senate) that represents the interests of 
Autonomies as Autonomies. But Spain lacks more than formal venues for the development of a collective subnational politics; it lacks even informal arrangements that might support such a politics.

In the United States, such institutions not only exist, but operate with great effectiveness. Informal organizations such as the National Governors' Association and the National Conference of State Legislatures serve as informational clearing houses for all states, develop common policy positions and common legislative responses to national initiatives, and coordinate collective lobbying efforts on behalf of collective subnational interests. In Spain, no such organizations exist. ${ }^{97}$ Leaders of the Autonomous Communities deal with one another independently, through the intermediation of nationwide political parties, or not at all. There is, in short, no institutional arrangement in which Autonomous Communities cooperate as Communities with a set of shared institutional interests.

\section{Impact of Requirement of Central Approval of Subnational Autonomy}

Finally, the Spanish constitutional rules structuring the process by which self-governing subnational units acquire autonomy very likely contribute to the problems of national-subnational relations in Spain. Under the Spanish Constitution, Autonomous Communities must gain central approval for each element of subnational autonomy they seek to adopt, and the process by which the Constitution requires that they obtain this permission is a petition to the central parliament, followed by a formal process of negotiation, after which the

96

Simon Barton, A History of Spain 139 (2004).

97 However, plans to create such an organization may soon be formulated. See El Pais, Hacia una conferencia de comunidades autónomas, March 11, 2009, http://www.elpais.com/articulo/cataluna/conferencia/ comunidades/autonomas/elpepiespcat/20090311elpcat_17/Tes/. 
central authority may grant the petition or not in its complete discretion. ${ }^{98}$ This arrangement thus demands that the Autonomies approach the Spanish state in the capacity of one sovereign addressing another, and even worse, in the capacity of a weak sovereign seeking the grace of a stronger one - a transaction not unlike ones that were commonplace during an earlier period of Spanish history: a vassal coming on bended knee to the royal court to seek privileges from a monarch.

This kind of institutional structure, it seems to us, has two effects that might impede the emergence of a stable and sustainable decentralized state. First, forcing subnational units continually to seek the blessing of the central state as a condition of undertaking autonomous self-government simply encourages the continual politicization of national-subnational relations. In the United States and in most other federal states, by contrast, questions of subnational autonomy are answered not by the politically bestowed grace of the central state, but by law, inscribed permanently in the national constitution. In such systems, subnational units decide what powers to exercise based on their own best interpretations of the constitution, not on their political estimation of what the central state might be willing to tolerate. If they attempt to exceed their constitutionally authorized powers, they will be called to account not by whatever political opposition rivals are able opportunistically to marshal within the central government, but by courts impartially enforcing the law.

Second, the Spanish system of requiring central approval reinforces subnational corporate identity in ways that are not necessarily beneficial. One of the strengths of federal systems, and a source of their capacity for endurance, is the way in which they complicate the identity of subnational units. A provincial government in a federal system is for some purposes the 
democratically legitimate voice of a distinct self-governing polity, yet for other purposes is nothing more than a geographically organized constituency of the national polity. ${ }^{99}$ When a subnational government petitions the central state for benefits in its capacity as only one of many national constituencies, the decision is much more likely to be framed and understood on both sides as resting on the ordinary distributional and administrative considerations upon which national governments routinely rely. When, on the other hand, a subnational government approaches the central state as a sovereign seeking permission to rule its own people, the possibility is increased that any decision will be understood as reflecting considerations of corporate bilateral relations that are unique to the subnational unit making the request. By forcing Autonomous Communities to petition and negotiate for the very powers that will make them self-governing polities, the Spanish constitutional system tends to force the transaction into the second, more highly charged mold. This reinforces subnational corporate identity as something distinct from national identity, thereby promoting precisely the sense of regional identity and nationalism that the Spanish Constitution was intended to manage.

In no case is this tendency more starkly evident than in the extremely tense and confrontational series of events surrounding the recent Basque petition to Parliament for approval of amendments to its Statute of Autonomy (the Ibarretxe Plan). The present Basque Statute of Autonomy was approved by Parliament in 1979. The Statute contains some unusual

99 See James A. Gardner, Whose Constitution Is It? Why Federalism and Constitutional Positivism Don’t Mix, 46 William \& Mary Law Review 1245 (2005). 
features, worked out as part of the 1978 Spanish constitutional settlement, that are based in historical rights of the Basque Country predating the Franco regime. ${ }^{100}$

In early 2005, the Basque Country forwarded to Madrid a set of dramatically revised amendments to its Statute of Autonomy. ${ }^{101}$ These amendments staked out a position on subnational autonomy far more extreme than any previously proposed by an Autonomous Community. The Preamble, in language that could not have been understood as anything but provocative, referred to the Basque as "a People with its own identity within the community of European peoples," and claimed for that people "the right to decide their own future . . . in accordance with the right to self-determination of all peoples." ${ }^{\prime 102}$ The working provisions of the proposed Statute described the Basque right of self-determination as the right to "form a Basque Community, freely associated with the Spanish State"; ${ }^{103}$ recognized a right of residents of the Basque Community to "Basque citizenship"; ${ }^{104}$ and extended Basque citizenship and political rights to members of the "Basque diaspora," wherever located. ${ }^{105}$

The proposed amendments also authorized the conclusion of agreements and joint ventures with the neighboring Autonomous Community of Navarre, in direct contravention of Article 145 of the Spanish Constitution, which, the relevant provision claimed, "shall not,

100 E.g., the Basque Country is the only Autonomy that received full fiscal and tax competencies, based in a law of 1876. It also has authority to operate an independent regional police force. See Ley 28/2007, October 25th de Concierto Economico con la Comunidad Autonoma Vasca.

101 http://www.nuevoestatutodeeuskadi.net/docs/dictamencomision20122004_eng.pdf.
102 Political Statute of the Community of the Basque Country (2004), preamble.
103 Id., Art. 1.
104 Id., Art. 4.
105 Id., Art. 5.


therefore, be applicable" to such agreements; ${ }^{106}$ and declared the right of the Basque Community to "direct representation in the organisations of the European Union." 107 The document also authorized the Basque citizenry to decide by referendum whether to "make complete or substantial changes in the format and regime of political relations with the Spanish State, as well as their relations with Europe and the international community," and purported to direct the Spanish state to respect such decisions; ${ }^{108}$ and purported to replace the authority of the Spanish Constitutional Court to decide questions of the constitutionality of the exercise of national and subnational power with a bilateral commission in which any differences would be worked out politically. ${ }^{109}$ In short, the amendments proposed a framework for a unilateral Basque decision to leave the Spanish state, and did so in a way that did not express a great deal of respect for the existing Spanish Constitution. ${ }^{110}$

This proposal was met with immediate and intense hostility by the Spanish government, the political parties, the media, and even, ominously, the military. Under the Spanish Constitution, proposed amendments to Statutes of Autonomy are to be taken up initially by a parliamentary committee for the purpose of negotiating an agreement between the Autonomy and the central state. ${ }^{111}$ Such a negotiation in this case was refused outright, and the 
government indicated that it had no intention of taking legislative action of any kind on the Basque proposal. The Basque President then responded by proposing that a referendum be put to the Basque electorate on questions indirectly relevant to the larger issue of Basque self-determination. ${ }^{112}$ The Spanish government then filed suit in the Spanish Constitutional Court to block such a referendum. In a 2008 ruling, the Constitutional Court declared the referendum beyond the scope of subnational competence under the Spanish Constitution. ${ }^{113}$ The Basque Country has since threatened repeatedly to challenge this decision in the European Court of Human Rights, although at this writing has not yet done so.

Based on our private interviews of Basque officials, including Lekhendakari (Basque President) Juan José Ibarretxe Markuartu, ${ }^{114}$ we believe that an important factor contributing to this unfortunate escalation of conflict was a miscalculation on the part of Basque leaders that is traceable in large part to the constitutional structure for amending Statutes of Autonomy. Consistent with the structure and sequence of constitutional formalities, Basque officials understood the process for amending their Statute of Autonomy as one of sovereign-to-sovereign political negotiations. Accordingly, they conceived of the initial draft of proposed amendments as an opening position in what they expected would be a multi-round process of negotiations. Like many parties entering what they understand to be a potentially complex negotiation, the Basques took an opening position that was considerably more extreme than the position at which

112 The questions were: (1) Are you in agreement in supporting a negotiated end to the violence, if ETA beforehand and in an unmistakable way, undertakes to abandon violence for ever? (2) Are you in agreement that the Basque political parties, without exclusions, start a process of negotiation to reach a democratic agreement on the rights of the Basque people to decide, and that such an agreement be subjected to a referendum before the end of 2010? President of the Basque Government Reveals His Two First Referendum Questions, TypicallySpanish.com (May 28, 2008). Sentencia 103/2008, (Sept. 11, 2008). 
they expected to arrive by the conclusion of the negotiations. In the event, this turned out to be a miscalculation because the Basque opening position was perceived by the Spanish state as being so far beyond the bounds of potential agreement as to make any discussion a waste of time.

However, both parties understood correctly that, in the context of the amendment proceedings, the negotiation would not be between the Spanish state and one of its constituency groups, but between the Spanish state and the Basque Autonomous Community in its corporate or quasi-sovereign capacity. Consequently, the Spanish rejection of the Basque position was understood by all concerned as a rejection of a certain claim to self-governance by a unique polity seeking recognition of its autonomy. Such a rejection is not legal but fundamentally political, and strikes not at the distributional aspirations of a national constituency but at the aspirations for sovereignty of a self-constituting political community. This isn't just business; it's personal. And this background context, in turn, helps explain why neither party thus far has found the will to turn back from the path of continuing escalation of the level of confrontation.

\section{CONCLUSION}

Sustainable federalism may well be the form of territorial organization most conducive to the long-term safety and prosperity of the modern state. We have argued here that constitutional design matters to the sustainability of decentralized power, but in ways that are different from those conventionally advanced. It is typically thought that the critical feature in the constitutionalization of a sustainable federalism is a symmetrical distribution of power between the national and subnational levels. But this is not necessarily the case because subnational units are frequently able to develop extraconstitutional methods for influencing national power 
that can alter the balance contemplated by formal constitutional structures and allocations of power. This has been true in both the United States and Spain.

A more important factor in the sustainability of decentralization, we believe, is symmetry among subnational units in their relation to the central state. In the United States, a highly stable federal state, symmetrical relations between the states and the central government have facilitated the successful checking of national power by the states acting collectively and more or less in unison. In Spain, by contrast, asymmetrical relations between Autonomous Communities and the central state permit the indulgence of potentially destructive rivalries at the subnational level that the state may in turn be able to exploit. This asymmetry may prevent the subnationalities from mounting successful efforts to check national power, thereby endangering the stability of the state and the long-term prosperity and liberty of its citizens. The most important problem of political design now facing Spain is therefore how to bring the subnational units into a common relation to the central state. 